\title{
Respiratory problems among cotton textile mill workers in Ethiopia
}

\author{
Mentesinot Woldeyohannes, Yves Bergevin, Amani Yacob Mgeni, Gilles Theriault
}

\begin{abstract}
This study was conducted to investigate the prevalence of respiratory problems, in particular byssinosis, and to explore factors associated with their occurrence among a group of 595 randomly selected workers representing $40.5 \%$ of those exposed to dusty operations in a typical Ethiopian cotton textile mill. A standard questionnaire on respiration was administered and pre and postshift forced vital capacity (FVC) and forced expiratory volume in one second $\left(F E V_{1}\right)$ were determined for each worker; workers found to have byssinosis and other respiratory diseases were compared with workers having no respiratory diseases in terms of the level and duration of exposure to cotton dust and other variables. Multiple area air samples from different sections were analysed for elutriated cotton dust concentrations $\left(0.86-3.52 \mathrm{mg} / \mathrm{m}^{3}\right)$. The prevalence of byssinosis was $43 \cdot 2 \%$ among blowers and $37.5 \%$ in carders in comparison with four to $24 \%$ among workers in other sections. Prevalence of chronic bronchitis ranged from 17.6 to $47 \cdot 7 \%$ and bronchial asthma from $8 \cdot 5$ to $20.5 \%$ across all sections. Significant across shift decrements in FEV ${ }_{1}$ and FVC were seen in those workers with respiratory tract diseases compared with those workers without such diseases. A significant dose response relation for pulmonary function and respiratory illnesses was also found by regression analysis.
\end{abstract}

Department of Community Health, Faculty of Medicine, Addis Ababa University, Ministry of Health, Addis Ababa, People's Democratic Republic of Ethiopia, and School of Occupational Health, McGill University, Montreal, PQ, Canada

$M$ Woldeyohannes

International Health Program and Departments of Epidemiology and Biostatistics and of Family Medicine, McGill University, Montreal, PQ, Canada Y Bergevin

Representative Office, World Health Organisation, Addis Ababa, People's Democratic Republic of Ethiopia

A Y Mgeni

School of Occupational Health, McGill University, Montreal, PQ, Canada

G Theriault
Preventive measures are proposed. Further research including a nationwide survey of textile mills is suggested. This is the first epidemiological study of the textile industry in Ethiopia.

Byssinosis caused by inhalation of cotton dust is a continuing problem and occurs world wide. Cotton production and use have expanded rapidly in developing countries. The Peoples' Democratic Republic of Ethiopia, one of the cotton producing and consuming countries in Africa, started expanding its textile industries during the last decade and the number of people working in the processing of cotton continues to increase annually.

Many studies in cotton mills have been reported from developed nations and a few reports regarding respiratory problems and cotton dust have been documented from developing countries such as Egypt, ${ }^{1}$ Sudan, ${ }^{2}$ Tanzania, ${ }^{3}$ and Hong Kong. ${ }^{4}$ No articles have been published, however, concerning the problems caused by cotton dust in Ethiopia. Thus this paper is the first epidemiological study of the textile industry in Ethiopia and uses diagnostic criteria similar to those applied in developed countries such as the United States and Great Britain.

A few studies of cotton textile workers have examined the prevalence of respiratory symptoms and lung function compared with those of control subjects. ${ }^{5-8}$ Also, a few have reviewed lung function in cotton textile workers with and without byssinosis or bronchitis. ${ }^{9-11}$ Our study investigated the prevalence of byssinosis and other respiratory problems among workers exposed to cotton dust in a textile mill in Ethiopia and also attempted to explore determinants by comparing the effect of cotton dust exposure of workers with respiratory tract diseases with those without such diseases.

The cotton textile mill was established in the early 1960s and a daily eight hourly shift system operates continuously for the whole week, intermittently providing a "day off”' for each worker to rest. Despite an attempt to retrofit current ventilation systems in the early 1980s, plant officials have stated that the dusty environment has remained unchanged since the mill was established. ${ }^{12}$ 


\section{Methods}

DESIGN

A cross sectional study was conducted during 1986 on over $40 \%$ of workers exposed to dusty operations in a cotton textile mill in Bahir Dar, Ethiopia.

\section{POPULATION}

The study population consisted of 595 workers ( 322 men and 273 women) selected randomly from a total of 1470 workers concerned with dusty operations in the blowing, carding, drawing, simplex, ringframe, preparatory, and weaving sections of a cotton textile mill that hired about 3500 workers overall. All workers selected participated in the study.

\section{ENVIRONMENTAL ASSESSMENT}

The concentration of airborne cotton dust in the general environment was monitored with an Anderson dust sampler fitted with a vertical elutriator (General Metal Works Inc) and placed at a height of $1.5 \mathrm{~m}$ in selected positions. Samples were drawn at a rate of $7 \cdot 4 \mathrm{l} / \mathrm{min}$. Multiple area samples were taken and the duration of sampling ranged between eight and 10 hours (mean 8.7 hours). The environmental monitoring was conducted by the principal investigator. All samples were collected on a Whatman glass fibre GF/A filter having a $3.7 \mathrm{~cm}$ diameter to fit the sampling heads. Weighing was on a calibrated analytical balance before and after sample collection, by a chemist at the Polytechnic Institute analytical chemistry laboratory (Bahir Dar, Gojjam) after equilibrating filters in the laboratory for 24 hours. The concentration of cotton dust was calculated according to the equation:

$$
\begin{aligned}
& \text { concentration }\left(\mathrm{mg} / \mathrm{m}^{3}\right)= \\
& \frac{(\text { final weight }- \text { initial weight })}{\text { time in minutes } \times \text { flow rate }} \times 1000
\end{aligned}
$$

\section{INTERVIEWS AND PHYSICAL EXAMINATION}

A modified version of the British Medical Research Council questionnaire (available upon request) was completed and each worker was fully examined with emphasis on signs and symptoms suggestive of respiratory diseases. All workers were interviewed and examined by the principal investigator who had no previous knowledge of the workers' section and health state.

The stages of byssinosis were defined to allow for subdivision according to the clinical grades suggested by Schilling et al. ${ }^{13}$ Subjects who complained of chronic and recurrent cough or phlegm on most days for at least three months a year for two successive years were diagnosed as having chronic bronchitis. ${ }^{14}$ Subjects with recurrent attacks of paroxysmal dyspnoea accompanied by wheezing that was relieved by antispasmodic drugs were diagnosed as having bronchial asthma. ${ }^{15}$ Subjects who complained of sneezing, rhinorrhoea, obstruction of the nasal passages, conjunctival and pharyngeal itching, and lacrimation were diagnosed as having hay fever. ${ }^{16}$

\section{PULMONARY FUNCTION TESTS}

Forced vital capacity (FVC) and forced expiratory volume in one second $\left(\mathrm{FEV}_{1}\right)$ were measured by a technician using a multipurpose spirometer. The spirometer was calibrated for volume, time, and flow before each testing session. Care was taken to ensure that the instrument was horizontally placed and none of the air venting slots were obscured. Measurements were taken on the subject sitting upright with the nose clipped. Function testing was carried out on each worker on the first day of the shift after at least two days absence from work and repeated at the end of the same shift. Five expiratory efforts were recorded and the mean of the two highest values was used to estimate the $\mathrm{FEV}_{1}$ and FVC. All volumes were adjusted to body temperature and pressure saturated with water vapour. The preshift $F E V_{1}$ values were compared with the expected normal values given by Cherniack and Raber. ${ }^{17}$

\section{DATA ANALYSIS}

The prevalence of byssinosis, chronic bronchitis, bronchial asthma, and other respiratory tract symptoms was determined. The relative magnitude (ratio) of proportions between variables was also established. Then a comparison of means and proportions was carried out for the airborne dust concentration and the prevalence of byssinosis and other respiratory problems, and between categories of smoking, by $\chi^{2}$ analysis and $t$ test.

The acute changes in $\mathrm{FEV}_{1}$ over the work shift were expressed as:

$$
\frac{\text { preshift } \mathrm{FEV}_{1}-\text { postshift } \mathrm{FEV}_{1}}{\text { preshift } \mathrm{FEV}} \times 100=\Delta \mathrm{FEV}_{1} \%
$$

The acute changes among byssinotic subjects and between byssinotic subjects and workers having no respiratory tract disease were compared using $\chi^{2}$ analysis. The acute changes in $F_{E V}$ during exposure to cotton dust were analysed according to Bouhuys et al (a fall in $\mathrm{FEV}_{1}$ of less than 0.061 was considered as a non-acute effect, between 0.06 and 0.21 as a slight effect, and more than 0.21 as a definite effect). ${ }^{18}$

The chronic changes in $\mathrm{FEV}_{1}$ among exposed workers were also analysed according to Bouhuys et al. ${ }^{18}$ Workers with $\mathrm{FEV}_{1}$ greater than $80 \%$ of the predicted values were considered to have no chronic ventilatory impairment, those with $\mathrm{FEV}_{1} 60$ to $80 \%$ slight to moderate, and those with $\mathrm{FEV}_{1}$ less than $60 \%$ to have from moderate to severe impairment. 
Finally, the relative contribution of the independent determinant variables to the occurrence of byssinosis and other respiratory problems was examined by multiple regression analysis and estimates of risk were derived.

For each statistical test $\mathrm{p}<0.05$ was considered significant.

\section{Results}

POPULATION

All 595 workers in the study underwent interview, physical examination, and testing of pulmonary function. Only 14 of the cohort were smokers and four were ex-smokers; all 18 were men. Over $95 \%$ of the cotton workers had not changed jobs or sections during the course of their employment.

\section{ENVIRONMENTAL ASSESSMENT}

Table 1 shows the concentrations of airborne cotton dust. The highest concentrations were recorded in the blowing and carding sections and the lowest in the weaving and preparatory sections. The amount of dust generated in the blowing and carding operations was more than twofold higher than that in other operations and the difference was significant.

\section{RESPIRATORY CONDITIONS}

A total of $50.6 \%$ of the study population had one or more respiratory tract problems; the remaining $49.4 \%$ had neither symptoms and signs nor a history of respiratory tract disease. Table 2 summarises the prevalence of byssinosis and other respiratory tract diseases. The prevalence of byssinosis, chronic bronchitis, and bronchial asthma was high $(\mathrm{p}<0.001)$ among blowers and carders in comparison with those in other sections. The overall prevalence of hay fever $(28.3 \%)$ was the highest of all the respiratory problems. Overall, the prevalence of byssinosis, chronic bronchitis, and bronchial asthma showed a significant increase with duration of exposure to cotton dust (table 3). No significant difference was seen in the prevalence of byssinosis between smoking and non-smoking workers; the effect of smoking on

Table 1 Concentration of airborne cotton dust in study sections by area sampling

\begin{tabular}{|c|c|c|c|}
\hline Section & $\begin{array}{l}\text { No of } \\
\text { samples }\end{array}$ & $\begin{array}{l}\text { Area } \\
(m g /\end{array}$ & $\begin{array}{l}\text { sampling } \\
n^{3} ; \text { mean (SD)) }\end{array}$ \\
\hline $\begin{array}{l}\text { Blowing (1) } \\
\text { Carding (2) } \\
\text { Drawing (3) } \\
\text { Simplex (4) } \\
\text { Ringframe (5) } \\
\text { Preparatory (6) } \\
\text { Weaving (7) }\end{array}$ & $\begin{array}{l}14 \\
18 \\
11 \\
11 \\
21 \\
12 \\
25\end{array}$ & $\begin{array}{l}3.52 \\
3 \cdot 21 \\
1.62 \\
1 \cdot 29 \\
1 \cdot 19 \\
0.92 \\
0.86\end{array}$ & $\begin{array}{l}(0.98) \\
(1.09) \\
(0.44) \\
(0.32) \\
(0.49) \\
(0.23) \\
(0.35)\end{array}$ \\
\hline
\end{tabular}

Level of significance; (1) $v(2) \mathrm{p}>0.05$; (1) $v(3)-(7) \mathrm{p}<0.0005$ (2) $v(3)-(7) \mathrm{p}<0.005$. the prevalence of chronic bronchitis was significant (table 4).

\section{ANALYSIS OF PULMONARY FUNCTION TESTS}

A total of 32 cotton textile workers (11 with byssinosis and 21 non-byssinotic subjects) out of the 595 study population $(5.4 \%)$ had unacceptable curves either by the reproducibility criteria or by an inability to perform any forced expiratory manoeuvre and these were excluded from the pulmonary function analysis.

Statistically significant $(p<0.001)$ across shift

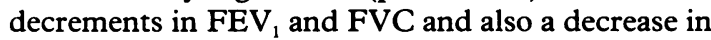
the percentage predicted $F E V_{1}$ were noted in the respiratory tract diseases group when compared with the group without such diseases. The acute changes in $\mathrm{FEV}_{1}$ during exposure to cotton dust were analysed (table 5) according to Bouhuys et al $^{18}$ and statistically significant acute effects were seen in byssinotic subjects compared with those without respiratory tract diseases $(p<0.001)$. Also, a significant increase in percentage reduction in $\mathrm{FEV}_{1}$ was noted with an increase in grade of byssinosis. The chronic changes in $\mathrm{FEV}_{1}$ among exposed workers were further analysed according to Bouhuys et $\mathrm{al}^{18}$; whereas $20 \%$ of byssinotics developed moderate to severe chronic changes in FEV 1 ( $<<0.001)$, only $1 \%$ of the workers with no respiratory tract disease showed similar changes (table 6).

Table 7 shows the regression coefficients for several indices of exposure derived from multiple regression models for $\triangle \mathrm{FEV}_{1} \%, \Delta \mathrm{FVC} \%$, prevalence of byssinosis, chronic bronchitis, bronchial asthma, and hay fever. The regression analysis was controlled for age, height, weight, and sex. The results indicate a highly significant $(\mathrm{p}<0.001)$ dose response relation between across shift percentage changes in $\mathrm{FEV}_{1}$ and FVC and cumulative cotton dust concentration, and also between the prevalence of byssinosis and all indices of dust exposure.

A significant dose response relation with cumulative exposure to cotton dust $(p<0.001)$ and with duration of employment in the cotton textile mill ( $p<0.05$, one tail test) was shown by the chronic bronchitis prevalence model.

Models for bronchial asthma and hay fever prevalences indicate a significant dose response relation with cumulative cotton dust exposure $(p<0.05$, one tail test). No significant relation with current cotton dust exposure was found. Prevalence models for hay fever and bronchial asthma showed a significant relation $(p<0.01$ and $p<0.05)$ with duration of employment in the cotton textile mill.

Models for $\triangle \mathrm{FEV}_{1}$ and $\triangle \mathrm{FVC}$ showed a highly significant relation $(p<0.001)$ with time weighted cotton dust concentration; no significant relation was found, however, between exposure to cotton dust and duration of employment. 
Table 2 Prevalence of byssinosis, chronic bronchitis, and bronchial asthma among workers exposed to cotton dust

\begin{tabular}{|c|c|c|c|c|c|c|c|c|c|}
\hline \multirow{2}{*}{$\begin{array}{l}\text { Section } \\
\text { Blowing } \\
\text { Carding } \\
\text { Drawing } \\
\text { Simplex } \\
\text { Ringframe } \\
\text { Preparatory } \\
\text { Weaving } \\
\text { Total }\end{array}$} & \multirow{2}{*}{$\begin{array}{l}\begin{array}{l}\text { No } \\
\text { examined }\end{array} \\
44 \\
40 \\
25 \\
42 \\
174 \\
128 \\
142 \\
595\end{array}$} & \multicolumn{2}{|c|}{$\begin{array}{l}\text { Duration of } \\
\text { exposure (months; } \\
\text { mean (SD)) }\end{array}$} & \multicolumn{2}{|c|}{$\begin{array}{l}\text { Byssinosis } \\
(N o(\%))\end{array}$} & \multicolumn{2}{|c|}{$\begin{array}{l}\text { Chronic bronchitis } \\
(\text { No }(\%))\end{array}$} & \multicolumn{2}{|c|}{$\begin{array}{l}\text { Bronchial } \\
\text { asthma } \\
(N o(\%))\end{array}$} \\
\hline & & $\begin{array}{l}201 \cdot 9 \\
200 \cdot 7 \\
239 \cdot 6 \\
235 \cdot 3 \\
233 \cdot 1 \\
222 \cdot 9 \\
238 \cdot 7 \\
218 \cdot 3\end{array}$ & $\begin{array}{l}(87 \cdot 2) \\
(74.8) \\
(68.5) \\
(69.4) \\
(73.2) \\
(71.5) \\
(67.0) \\
(79.5)\end{array}$ & $\begin{array}{r}19 \\
15 \\
6 \\
10 \\
30 \\
14 \\
6 \\
100\end{array}$ & $\begin{array}{l}(43 \cdot 2)^{\star \star \star} \\
(37 \cdot 5)^{\star \star \star} \\
(24 \cdot 0) \\
(23 \cdot 8) \\
(17 \cdot 2) \\
(10 \cdot 9) \\
(4 \cdot 2) \\
(16 \cdot 8)\end{array}$ & $\begin{array}{r}21 \\
18 \\
8 \\
10 \\
32 \\
23 \\
25 \\
137\end{array}$ & $\begin{array}{l}(47 \cdot 7)^{\star \star \star} \\
(45 \cdot 0)^{\star \star \star} \\
(32 \cdot 0) \\
(23 \cdot 8) \\
(20 \cdot 7) \\
(18 \cdot 0) \\
(17 \cdot 6) \\
(23 \cdot 0)\end{array}$ & $\begin{array}{r}9 \\
5 \\
3 \\
3 \\
17 \\
15 \\
12 \\
64\end{array}$ & $\begin{array}{l}(20 \cdot 5)^{\star \star \star} \\
(12 \cdot 5) \\
(12 \cdot 0) \\
(7 \cdot 1) \\
(9 \cdot 8) \\
(11 \cdot 7) \\
(8 \cdot 5) \\
(10 \cdot 8)\end{array}$ \\
\hline
\end{tabular}

$\star \star \star p<0.001$.

Table 3 Duration of exposure and prevalence of byssinosis, chronic bronchitis, and bronchial asthma

\begin{tabular}{|c|c|c|c|c|}
\hline $\begin{array}{l}\text { Duration of exposure } \\
(y)\end{array}$ & No examined & Byssinosis (No (\%)) & Chronic bronchitis (No (\%)) & $\begin{array}{l}\text { Bronchial asthma } \\
(\text { No }(\%))\end{array}$ \\
\hline $\begin{array}{l}<10 \\
10-19 \\
\geqslant 20 \\
\text { Total }\end{array}$ & $\begin{array}{l}105 \\
208 \\
282 \\
595\end{array}$ & $\begin{aligned} 6 & (5 \cdot 7) \\
25 & (12 \cdot 0) \\
69 & (24 \cdot 5) \\
100 & (16 \cdot 8) \text { p }<0.001\end{aligned}$ & $\begin{aligned} 17 & (16 \cdot 2) \\
43 & (20 \cdot 7) \\
77 & (27 \cdot 3) \\
137 & (23 \cdot 0) \text { p }<0.05\end{aligned}$ & $\begin{aligned} 2 & (1.9) \\
12 & (5.8) \\
50 & (17 \cdot 7) \\
64 & (10.8) \text { p }<0.001\end{aligned}$ \\
\hline
\end{tabular}

Table 4 Effect of smoking on the prevalence of byssinosis, chronic bronchitis, and bronchial asthma among workers exposed to cotton dust

\begin{tabular}{|c|c|c|c|c|c|}
\hline Group & $\begin{array}{l}\text { No } \\
\text { examined }\end{array}$ & $\begin{array}{l}\text { Duration of } \\
\text { exposure (months } \\
\text { mean SD)) }\end{array}$ & $\begin{array}{l}\text { Byssinosis } \\
(\operatorname{No}(\%))\end{array}$ & $\begin{array}{l}\text { Chronic } \\
\text { bronchitis } \\
(\text { No }(\%))\end{array}$ & $\begin{array}{l}\text { Bronchial } \\
\text { asthma } \\
(\text { No }(\%))\end{array}$ \\
\hline $\begin{array}{l}\text { Smokers } \\
\text { Non- or ex-smokers }\end{array}$ & $\begin{array}{r}14 \\
581\end{array}$ & $\begin{array}{ll}205 \cdot 2 & (89 \cdot 2) \\
218 \cdot 4 & (79 \cdot 2)\end{array}$ & $\begin{aligned} 3 & (21 \cdot 4) \\
97 & (16 \cdot 7)\end{aligned}$ & $\begin{aligned} 9 & (64 \cdot 3)^{\star \star \star} \\
128 & (22 \cdot 0)\end{aligned}$ & $\overline{64}(11 \cdot 0)$ \\
\hline
\end{tabular}

$\star \star \star p<0.001$.

Table 5 Acute changes in FEV during dust exposure $(>0 \cdot 2 l) \dagger$

\begin{tabular}{|c|c|c|c|c|c|}
\hline \multirow[b]{3}{*}{$\begin{array}{l}\text { Section } \\
\text { Blowing } \\
\text { Carding } \\
\text { Drawing } \\
\text { Simplex } \\
\text { Ringframe } \\
\text { Preparatory } \\
\text { Weaving } \\
\text { Total }\end{array}$} & \multicolumn{2}{|c|}{ No respiratory tract disease } & \multicolumn{3}{|c|}{ Byssinosis (all groups) } \\
\hline & No examined & $\begin{array}{l}\text { No (\%) with acute changes } \\
\text { in FEV }\end{array}$ & No examined & & $\begin{array}{l}\text { (\%) with acute changes } \\
E V_{1}^{\star \star \star}\end{array}$ \\
\hline & $\begin{array}{r}18 \\
15 \\
7 \\
20 \\
91 \\
70 \\
73 \\
294\end{array}$ & $\begin{aligned} 6 & (33 \cdot 3) \\
7 & (46 \cdot 7) \\
3 & (42 \cdot 9) \\
7 & (35 \cdot 0) \\
31 & (34 \cdot 1) \\
17 & (24 \cdot 3) \\
20 & (27 \cdot 4) \\
91 & (31 \cdot 0)\end{aligned}$ & $\begin{array}{r}17 \\
13 \\
6 \\
9 \\
27 \\
11 \\
6 \\
89\end{array}$ & $\begin{array}{r}17 \\
13 \\
6 \\
7 \\
20 \\
8 \\
4 \\
75\end{array}$ & $\begin{array}{c}(100 \cdot 0) \\
(100 \cdot 0) \\
(100 \cdot 0) \\
(77 \cdot 8) \\
(74 \cdot 1) \\
(72 \cdot 7) \\
(66 \cdot 7) \\
(84 \cdot 3)\end{array}$ \\
\hline
\end{tabular}

Lung function was not recorded for 11 byssinotic subjects.

† Graded according to Bouhuys et al. ${ }^{18}$

$\star \star \star$ The acute change difference in $\mathrm{FEV}_{1}$ between byssinotic subjects and those with no respiratory tract disease was highly significant $(\mathrm{p}<0.001)$.

\section{Discussion}

Our study showed that the concentrations of airborne cotton dust in the different sections of the surveyed textile mill were high, with concentrations greatly in excess (four to 17 times) of $0.2 \mathrm{mg} / \mathrm{m}^{3}$ of dust-the threshold limit value recommended for cotton dust (American Conference of Governmental Industrial
Hygienists, 1983). ${ }^{19}$ This was in accordance with reports on other cotton mills in Sudan and England. ${ }^{2620}$ Also, the dust concentration collected at the early stage of yarn production was high and similar to that reported by others. ${ }^{2122}$

The high prevalence of byssinosis in the blowing and carding processes is similar to that reported by 
Table 6 Chronic changes in FEV, among byssinotic subjects and those with no respiratory tract disease

\begin{tabular}{|c|c|c|c|c|c|c|c|}
\hline \multirow{3}{*}{$\begin{array}{l}\text { Group } \\
\text { No respiratory tract disease } \\
\text { Byssinosis: }\end{array}$} & \multirow{3}{*}{$\begin{array}{l}\text { No } \\
\text { examined }\end{array}$} & \multicolumn{6}{|c|}{ Chronic changes in $\mathrm{FEV}_{1} \dagger$} \\
\hline & & \multicolumn{2}{|c|}{$\begin{array}{l}\text { No change; }>80 \% \text { of predicted } \\
(\text { No }(\%))\end{array}$} & \multicolumn{2}{|c|}{$\begin{array}{l}\text { Moderate; } 60-80 \% \text { of predicted } \\
(\text { No }(\%))\end{array}$} & \multicolumn{2}{|c|}{$\begin{array}{l}\text { Severe; } \leqslant 60 \% \text { of } \\
\text { predicted }(\text { No }(\%))\end{array}$} \\
\hline & & 210 & $(71 \cdot 4)$ & 81 & $(27 \cdot 6)$ & 3 & $(1 \cdot 0)$ \\
\hline $\begin{array}{l}\text { Grade } 1 / 2 \\
\text { Grade I } \\
\text { Grade II } \\
\text { All grades }\end{array}$ & $\begin{array}{l}34 \\
24 \\
31 \\
89\end{array}$ & $\begin{array}{r}20 \\
11 \\
9 \\
40\end{array}$ & $\begin{array}{l}(58 \cdot 8) \\
(45 \cdot 8) \\
(29 \cdot 0) \\
(44 \cdot 9)\end{array}$ & $\begin{array}{r}13 \\
8 \\
10 \\
31\end{array}$ & $\begin{array}{l}(38 \cdot 2) \\
(33 \cdot 3) \\
(32 \cdot 3) \\
(34 \cdot 8)\end{array}$ & $\begin{array}{r}1 \\
5 \\
12 \\
18\end{array}$ & $\begin{array}{l}(2 \cdot 9) \\
(20 \cdot 8) \\
(38 \cdot 7) \\
(20 \cdot 2)^{\star \star \star}\end{array}$ \\
\hline
\end{tabular}

$\star \star \star \mathrm{p}<0.001$

+ Graded according to Bouhuys et al..$^{18}$

+Lung function was not recorded for 11 byssinotic subjects.

Table 7 Regression coefficients for period of exposure, current cotton dust exposure, and cumulative cotton dust exposure in byssinosis, chronic bronchitis, bronchial asthma, hay fever, and pulmonary function models

\begin{tabular}{|c|c|c|c|}
\hline & $\begin{array}{l}\text { Duration of exposure } \\
\text { (months) }\end{array}$ & $\begin{array}{l}\text { Current exposure cotton dust } \\
\text { concentration }\left(\mathrm{mg} / \mathrm{m}^{3}\right)\end{array}$ & $\begin{array}{l}\text { Cumulative exposure cotton dust } \\
\text { concentration }\left(\mathrm{mg} / \mathrm{m}^{3}\right)\end{array}$ \\
\hline Byssinosis & $0.002^{\star \star \star}$ & $0 \cdot 308^{\star \star \star}$ & $0.001 \star \star \star$ \\
\hline Chronic bronchitis & $0.042 \dagger$ & 0.065 & $3.76 \mathrm{E}-04^{\star \star \star}$ \\
\hline Bronchial asthma & $0.066^{\star}$ & $0 \cdot 117$ & $0.075 \dagger$ \\
\hline Hay fever & $7 \cdot 14 \mathrm{E}-04^{\star \star}$ & 0.066 & $0.077 \dagger$ \\
\hline$\triangle \mathrm{FEV}_{1} \%$ & 0.427 & 0.054 & $0 \cdot 154^{\star \star \star}$ \\
\hline$\triangle \mathrm{FVC} \%$ & 0.005 & 0.006 & $0.060^{\star \star \star}$ \\
\hline
\end{tabular}

${ }^{\star} \mathrm{p}<0.05 ;{ }^{\star \star} \mathrm{p}<0.01 ;{ }^{\star \star \star} \mathrm{p}<0.001$

$+\mathrm{p}<0.05$ in one tail test (the hypothesis from the outset was unidirectional).

other investigators. ${ }^{23}$ Its high prevalence in drawing, simplex, and ringframe spinners may be because the concentration of cotton dust was also high in these sections.

Despite the controversy surrounding the relation between the prevalence of byssinosis and the duration of exposure, our study showed a significant increase in the prevalence of byssinosis with duration of exposure to cotton dust. The same relation has also been found in Sudan and Egypt. ${ }^{2021}$ The progression of the stages of byssinosis in relation to the duration of exposure support previously reported conclusions that the different grades of byssinosis follow each other in diseased subjects. ${ }^{2021}$ Our results also showed a significant association between the prevalence of byssinosis and time weighted dust concentration. This is in agreement with the studies of Fox et al. ${ }^{24}$ Smoking had no significant relation with the prevalence of byssinosis in our study, probably because of the small number of smokers.

Although previous investigators ${ }^{724}$ found that the prevalence of chronic bronchitis was not related to dust concentrations, the significant relation we found agrees with the findings of $\mathrm{El} \mathrm{Karim}{ }^{2}$ and Merchant et $a l^{25}$ Although cigarette smoking is the single most important etiological factor in causing chronic bronchitis, occupational and environmental exposures are now receiving more attention as possible contributions. This is supported by our findings.

We also showed that bronchial asthma was high among the blowers and had a significant relation with cumulative cotton dust exposure. Most subjects with asthma developed the problem after they had worked for several years in the textile mill. Even though most of these reported negative family histories of allergy, $34.4 \%$ had had intermittent symptoms of rhinitis that were mostly seasonal.

Our findings showed no significant relation between hay fever and current dust exposure but the relation of hay fever with duration of employment in the cotton textile mill and cumulative cotton dust exposure was significant. This finding may be because an allergic reaction does not occur on first exposure. The latent interval during which sensitisation occurs varies from a few weeks to many years. When hay fever and asthma first develop some years after an employee enters an industry, it is easy to understand that an occupational origin may be overlooked. In our study most hay fever cases developed the symptom complex after many years of work in the textile mill.

Even though there is some evidence that byssinosis is not more prevalent among atopic than non-atopic workers, ${ }^{26}$ our findings indicated that most byssinotic subjects $(55 \%)$ had a clear cut characteristic symptom complex of hay fever (allergic rhinitis). In agreement with this and as described by Jones $e t$ al $^{27}$ atopy might be an important risk factor in the development of byssinosis and this shows the importance of identifying atopic workers.

Our study showed that byssinotic subjects had significantly greater acute decrements in their $\mathrm{FEV}_{1}$ 
throughout a work shift than those without respiratory tract diseases, supporting the findings of earlier investigators. ${ }^{98} 29$ The cotton exposed workers with byssinosis also had a significant chronic change in $\mathrm{FEV}_{1}$ when compared with those workers having no respiratory tract disease, which agrees with the findings of previous investigators. ${ }^{289} 9$ 30-32

In conclusion, our findings suggest that the higher the concentration of cotton dust and the longer a person is exposed to it, the higher the risk of developing byssinosis, chronic bronchitis, bronchial asthma, and other respiratory problems. This signifies a high occupational health hazard that merits attention. Also, an immunological dysfunction such as atopy may be a risk factor in the development of respiratory disease induced by cotton dust. Bearing in mind that cotton dust has a diverse content as described by many investigators, the extent of association between exposure to cotton dust and chronic bronchitis, bronchial asthma, and hay fever and also the extent of development of byssinosis and other respiratory problems among atopic and nonatopic workers should be further investigated and analysed in depth.

We acknowledge and thank Drs Getachew Tadesse, Zein Ahmed Zein, Gebreselassie Okubagzi, Yemane Asgedom, and all the colleagues who contributed so much to the successful completion of this study. We are greatly indebted to the International Development and Research Centre for generously funding this project. We also thank Drs Charles Larson and Francis Aboud for their kind advice.

Requests for reprints to: $\operatorname{Dr} M$ Woldeyohannes, School of Occupational Health, McGill University, 1130 Pine Avenue West, Montreal, PQ, Canada H3A 1 A3.

1 El Batawi MA. Byssinosis in the cotton industry in Egypt. $\mathrm{Br} \mathrm{J}$ Ind Med 1962;19:126-30.

2 Awad El Karim MA, Osman Y, El Haimi YA. Byssinosis: environmental and respiratory symptoms among textile workers in Sudan. Int Arch Occup Environ Health 1986;57:101-8.

3 Mustafa KY. Byssinosis in Tanzanian textile workers. Lung 1969;159:39-44.

4 Morgan PGM, Ong SG. First report of byssinosis in Hong Kong. Br J Ind Med 1981;38:290-2.

5 Schilling RSF. Byssinosis in cotton and other textile workers. Lancet 1956;2:261-5.

6 Molyneux MKB, Tombleson JBL. An epidemiological study of respiratory symptoms in Lancashire mills, 1963-1966. Br J Ind Med 1970;27:225-34.

7 Berry G, Molyneux MKB, Tombleson JBL. Relationships between dust level and byssinosis and bronchitis in Lancashire cotton mills. Br J Ind Med 1974;31:18-27.

8 Schilling RSF. Epidemiological studies of chronic respiratory diseases among cotton operatives. Journal of Biological Medicine 1964;37:55-74.

9 Berry G, McKerrow CB, Rossiter CE, Tombleson JBL. A study of acute and chronic changes in ventilatory capacity of workers in Lancashire cotton mills. Br J Ind Med 1973;30:25-36.

10 Bouhuys A, Schoenberg JB, Beck GJ, Schilling RSF. Epidemiology of chronic lung disease in a cotton mill community. Lung 1977;154:167-86.

11 Mair A, Smith DA, Wilson WA, Lockhart W. Dust diseases in Dundee textile workers. Br J Ind Med 1960;17:272-8.

12 Woldeyohannes M. Health profile and plan of action for Bahir Dar Awraja. Addis Ababa: Ministry of Health, 1987.

13 Schilling RSF, Vigliani EC, Lammers B, Valic F, Gilson JC. A report on a conference on byssinosis. In: Proceedings of the 14 th international conference on occupational health, Madrid, 1963. Excerpta Medica 1964;2:137-45.

14 Fletcher CM. Chronic bronchitis. Am Rev Respir Dis 1959;80: 483-94.

15 Hinshaw HD, Garland LH. Diseases of the chest. 2nd ed. Philadelphia: WP Saunders, 1963:299-310.

16 Isselbacher KJ, Adams RD, Braunwald E, Petersdorf RG, Welson JD. Harrison's principles of internal medicine. 11th ed. Hamburg: McGraw-Hill Inc, 1987:1412-4.

17 Cherniack RM, Raber MB. Normal standards for ventilation function using an automated wedge spirometer. Am Rev Respir Dis 1972;106:38-46.

18 Bouhuys A, Gilson JC, Schilling RSF. Byssinosis in the textile industry. Arch Environ Health 1970;21:475-8.

19 American Conference of Governmental Industrial Hygienists. Threshold limit values. Cincinnati: ACGIH, 1983.

20 Awad El Karim MA, El Hag AA. Byssinosis and tuberculosis in cotton industry in Sudan. East Afr Med J 1985;62:491-500.

21 Noweir $\mathrm{MH}$, Noweir $\mathrm{KH}$, Ossman HA, Mossellin M. An environmental and medical study of byssinosis and other respiratory conditions in the cotton textile industry in Egypt. Am J Ind Med 1984;6:173-83.

22 Holness DL, Taraschuk LG, Pelmear PL. Effect of dust exposure in Ontario cotton textile mills. J Occup Med 1983; 25:26-9.

23 Ong SG, Jam TH, Wong CM, Ma PL, Lam SK, O'Kelly EJ. Byssinosis in Hong Kong. Br J Ind Med 1985;42:499-520.

24 Fox AJ, Tombleson JBL, Watt A, Wilkie AG. A survey of respiratory diseases in cotton operatives. Part II. Symptoms, dust estimations, and the effect of smoking habit. Br J Ind Med 1973;30:48-53.

25 Merchant J, Lumsden JC, Kilburn $\mathrm{KH}$, et al. An industrial study of the biological effects of cotton dust and cigarette smoke exposure. J Occup Med 1973;15:212-21.

26 Bouhuys A. Asthma and byssinosis. Review of Allergy 1966;22: 473-6.

27 Jones RN, Butcher BT, Hammand YY, et al. Interaction of atopy and exposure to cotton dust in the bronchoconstrictor response. Br J Ind Med 1980;37:141-6.

28 McKerron CB, McDermoth M, Gelson JC, Schilling RSF. Respiratory function during the day in cotton workers: a study in byssinosis. Br J Ind Med 1958;15:75-83.

29 Buck M, Bouhuys A. A purified extract from cotton bracts induces airway constriction in humans. Chest 1981;79:43-9.

30 Beck GJ, Schachter EN. The evidence for chronic lung diseases in cotton textile workers. American Statistician 1983;37: 404-12.

31 Schachter EN, Maunder LR, Beck GJ. The pattern of lung function abnormalities in cotton textile workers. Am Rev Respir Dis 1984;129:523-7.

32 Beck GJ, Schachter EN, Maunder LR, Schilling RSF. A prospective study of chronic lung disease in cotton textile workers. An Int Med 1982;97:645-51.

Accepted 10 September 1990 